\title{
Enteric Dopaminergic Neurons: Definition, Developmental Lineage, and Effects of Extrinsic Denervation
}

\author{
Z. S. Li, ${ }^{1}$ T. D. Pham, ${ }^{1}$ H. Tamir, ${ }^{1,2}$ J. J. Chen, ${ }^{1}$ and M. D. Gershon ${ }^{1}$ \\ ${ }^{1}$ Department of Anatomy and Cell Biology, Columbia University, College of Physicians and Surgeons, New York, New York 10032, and ${ }^{2}$ Department of \\ Psychiatry, New York State Psychiatric Institute, New York, New York 10032
}

The existence of enteric dopaminergic neurons has been suspected; however, the innervation of the gut by sympathetic nerves, in which dopamine (DA) is the norepinephrine precursor, complicates analyses of enteric DA. We now report that transcripts encoding tyrosine hydroxylase $(\mathrm{TH})$ and the DA transporter (DAT) are present in the murine bowel (small intestine $>$ stomach or colon; proximal colon $>$ distal colon). Because sympathetic neurons are extrinsic, transcripts encoding TH and DAT in the bowel are probably derived from intrinsic neurons. TH protein was demonstrated immunocytochemically in neuronal perikarya (submucosal $\gg$ myenteric plexus; small intestine $>$ stomach or colon). TH, DA, and DAT immunoreactivities were coincident in subsets of neurons (submucosal $>$ myenteric) in guinea pig and mouse intestines in situ and in cultured guinea pig enteric ganglia. Surgical ablation of sympathetic nerves by extrinsic denervation of loops of the bowel did not affect DAT immunoreactivity but actually increased numbers of TH-immunoreactive neurons, expression of mRNA encoding TH and DAT, and enteric DOPAC (the specific dopamine metabolite). The fetal gut contains transiently catecholaminergic (TC) cells. TC cells are the proliferating crest-derived precursors of mature neurons that are not catecholaminergic and, thus, disappear after embryonic day (E) 14 (mouse) or E15 (rat). TC cells appear early in ontogeny, and their development/survival is dependent on mash-1 gene expression. In contrast, the intrinsic TH-expressing neurons of the murine bowel appear late (perinatally) and are mash-1 independent. We conclude that the enteric nervous system contains intrinsic dopaminergic neurons that arise from a mash-1-independent lineage of noncatecholaminergic precursors.

Key words: dopamine; dopamine transporter; tyrosine hydroxylase; enteric nervous system; sympathetic nerves; development

\section{Introduction}

The enteric nervous system (ENS) is larger and more complex than other regions of the PNS, reflecting the ability of the ENS to regulate enteric behavior in the absence of CNS input (Gershon et al., 1994; Gershon, 1999; Furness, 2000). Uniquely, the enteric plexuses contain intrinsic primary afferent neurons and interneurons that enable the ENS independently to mediate integrative responses to local stimuli. Many of the small molecule neurotransmitters that are found in the CNS have also been identified in the ENS. These include ACh (Steele et al., 1991; Li and Furness, 1998; Neunlist et al., 1999; Cooke, 2000; Furness, 2000; Galligan et al., 2000), norepinephrine (NE) (Leibl et al., 1999), 5-HT (Gershon, 2000), GABA (Krantis, 2000), and glutamate (Liu et al., 1997; Kirchgessner, 2001). All are the neurotransmitters of intrinsic enteric neurons, except NE, which is restricted to the enteric projections of extrinsic (sympathetic) neurons (Costa and Furness, 1984; Keast et al., 1984; Leibl et al., 1999). Although the bowel contains dopamine (DA) (Eaker et al., 1988), it has been difficult to determine whether enteric DA is

Received Aug. 28, 2003; revised Nov. 20, 2003; accepted Dec. 2, 2003.

This work was supported by National Institutes of Health Grants NS12969 and NS15547.

Correspondence should be addressed to Dr. Z. S. Li, Department of Anatomy and Cell Biology, Columbia Univer-

sity, College of Physicians and Surgeons, 630 West 168th Street, New York, NY 10032. E-mail: ZL64@columbia.edu. DOI:10.1523/JNEUROSCI.3982-03.2004

Copyright $\odot 2004$ Society for Neuroscience $\quad$ 0270-6474/04/241330-10\$15.00/0 present in intrinsic neurons or, because DA is the precursor of $\mathrm{NE}$, in the sympathetic innervation.

Indirect evidence supports the existence of enteric dopaminergic neurons: (1) DA immunoreactivity has been reported in gastric nerve fibers, and DA is released from the corpus of the guinea pig stomach by nerve stimulation (Shichijo et al., 1997); (2) enteric DA transporter (DAT)-immunoreactive nerves have been observed (Mitsuma et al., 1998); (3) the specific DA metabolite 3,4-dihydroxyphenylacetic acid (DOPAC) has been found in mouse intestine (Eaker et al., 1988); (4) the ratio of DA to NE is higher in the bowel than in other peripheral organs (Eaker et al., 1988); (5) enteric DA is depleted by 6-hydroxydopamine (Eaker et al., 1988); and (6) pharmacological studies of transgenic mice lacking DAT have suggested that the mouse colon may normally contain inhibitory dopaminergic neurons (Walker et al., 2000). Human enteric DA and DA-immunoreactive myenteric neurons have also been reported; moreover, DA is depleted from ganglion-containing layers of the gut in Parkinson's disease, which affects dopaminergic neurons (Singaram et al., 1995).

Transiently catecholaminergic (TC) cells are abundant in the murine bowel between embryonic day (E) 11 and E14 (Baetge and Gershon, 1989). TC cells, which express tyrosine hydroxylase (TH) and dopamine $\beta$-hydroxylase (DBH), also contain and take up NE (Cochard et al., 1978; Teitelman et al., 1978, 1981; Jonakait et al., 1979; Gershon et al., 1984b). TC cells are proliferating neuronal precursors (Teitelman et al., 1981; Baetge and Gershon, 
Table 1. Sequences of primers

\begin{tabular}{lllc}
\hline Primers & $\begin{array}{l}\text { GenBank } \\
\text { accession number }\end{array}$ & Primer sequence & $\begin{array}{c}\text { Primer location } \\
\text { in the sequence }\end{array}$ \\
\hline \multirow{3}{*}{$\beta$-Actin } & X03672 & Forward, 5' -TGT TTG AGA CCT TCA ACA CC-3' & $448-467$ \\
& & Reverse, 5' -CAG TAA TCT CCT TCT GCA TCC-3' & $1035-1015$ \\
DAT & AF109391 & Forward, 5' -CAA TTC CAC CCT CAT CAA CC-3' & $134-153$ \\
& & Reverse, 5' -ACG CTC AAA ATA CTC AGC AG-3' & $659-640$ \\
TH & M69200 & Forward, 5' -TAC CGA GAG GAC AGC ATT CC-3' & $798-817$ \\
\hline
\end{tabular}

cloned into pGEM-T Easy vectors (Promega, Madison, WI) by using the TA-cloning kit (Invitrogen, San Diego, CA). Inserts in two individual clones were sequenced by the dideoxynucleotide chain termination method (in the DNA Facility of Columbia University). The sequences of the PCR products obtained from brain and gut with the indicated primers were found to be identical to those of the corresponding GenBank sequences in cDNAs encoding mouse $\beta$-actin, DAT, and TH.

Real-time PCR. Real-time PCR was used to

1989; Baetge et al., 1990a,b) that express and share a dependence on the transcription factor mash-1 (Blaugrund et al., 1996). When TC cells terminally differentiate and acquire their definitive neurotransmitter, such as 5-HT, they lose TH, NE, and high-affinity uptake of NE. If enteric dopaminergic neurons exist, therefore, they would have to develop from a separate, late-arising, mash-1-independent neuronal lineage.

The current study was undertaken to test the hypothesis that the mouse intestine contains intrinsic dopaminergic neurons. We used immunoblots, immunocytochemistry, and reverse transcription (RT)-PCR to determine whether intrinsic enteric neurons express dopaminergic markers, including $\mathrm{TH}, \mathrm{DA}$, and DAT. Lineage was investigated by comparing perinatal wild-type and transgenic mice that lack mash-1. Our observations strongly support the idea that the mouse intestine contains intrinsic dopaminergic neurons that arise late in ontogeny from a mash-1independent lineage of precursor cells.

\section{Materials and Methods}

Animals and tissue preparation. Adult CD-1 mice (25-30 gm) and guinea pigs (200-350 gm) (Charles River, Wilmington, MA) of either sex were used for these studies. Transgenic mice lacking mash-1 were obtained from Dr. David Anderson (California Institute of Technology, Pasadena, CA) and have been described previously (Guillemot et al., 1993; Lo et al., 1994; Blaugrund et al., 1996). Adult mice and guinea pigs were killed for experimental purposes by $\mathrm{CO}_{2}$ inhalation. This procedure was approved by the Animal Care and Use Committee of Columbia University. Perinatal animals were anesthetized on ice and killed by decapitation. The brain, stomach, duodenum, ileum, and proximal and distal colon were removed from the animals and processed for molecular and histological studies. Mice that lacked the mash-1 transcription factor were obtained from timed pregnant C57BL6/J mice carrying a null allele in the mash-1 locus. mash-1-/- mice were identified by PCR analysis of a small piece of liver that was removed from each fetus, as described previously (Blaugrund et al., 1996). Fetuses were removed from pregnant dams at E17. The day at which a vaginal plug was found was designated as day 0 gestation.

RNA extraction and preparation of $c D N A$. The brain, stomach, duodenum, ileum, and proximal and distal colon were collected in PBS $(0.9 \%$ $\mathrm{NaCl}$ in $0.01 \mathrm{~m}$ sodium phosphate buffer, $\mathrm{pH} 7.4$ ), which had been treated with $0.1 \%$ diethyl pyrocarbonate (depc-PBS). After the wall of each piece of gut was opened, the tissue was cleaned with depc-PBS and transferred to Trizol (Invitrogen, Carlsbad, CA) for extraction of total RNA, which was isolated according to the manufacturer's instructions and stored at $-80^{\circ} \mathrm{C}$ for additional use. Samples of cDNA were generated by reverse transcription with $3 \mu \mathrm{g}$ of total RNA, $0.5 \mu \mathrm{g}$ of random hexamer primers, 0.5 mM dNTPs, $40 \mathrm{U}$ of RNAsin, and $400 \mathrm{U}$ of Maloney murine leukemia virus reverse transcriptase (Life Technologies), in a $30 \mu$ reaction volume.

PCR. Pairs of oligonucleotide primers for amplification of cDNA encoding $\beta$-actin, DAT, and TH were designed from published cDNA sequences of mouse $\beta$-actin, DAT, and TH (Table 1 ). PCR reactions for DAT were performed for 35 cycles $\left(94^{\circ} \mathrm{C}\right.$ for $30 \mathrm{sec}, 57^{\circ} \mathrm{C}$ for $60 \mathrm{sec}$, and $72^{\circ} \mathrm{C}$ for $30 \mathrm{sec}$ ). Because transcripts encoding $\beta$-actin and $\mathrm{TH}$ were abundant, only 30 cycles of amplification were used for $\beta$-actin $\left(94^{\circ} \mathrm{C}\right.$ for $30 \mathrm{sec}, 57^{\circ} \mathrm{C}$ for $45 \mathrm{sec}$, and $72^{\circ} \mathrm{C}$ for $\left.30 \mathrm{sec}\right)$ and $\mathrm{TH}\left(94^{\circ} \mathrm{C}\right.$ for $30 \mathrm{sec}, 58^{\circ} \mathrm{C}$ for $60 \mathrm{sec}$, and $72^{\circ} \mathrm{C}$ for $\left.30 \mathrm{sec}\right)$. The identity of PCR products was confirmed by sequence analysis. For this purpose, PCR products were sub- quantify mRNA encoding DAT and TH in the mouse stomach, duodenum, ileum, and proximal and distal colon. The expression of DAT and $\mathrm{TH}$ was normalized to that of $\beta$-actin, a housekeeping gene that is not thought to be subject to regulation. Transcripts encoding $\beta$-actin in samples of mouse gut were first quantified by real-time PCR with the SYBR Green I kit (Roche Molecular Biochemicals, Indianapolis, IN) using a LightCycler instrument (Roche). Measurements were obtained by referring to standard curves that were prepared by serially diluting plasmid DNA encoding DAT, TH, and $\beta$-actin. The dilutions of $\beta$-actin and TH plasmid DNA ranged from 1 pg to $10 \mathrm{ng}$ in five series, each of which covered a 10-fold range. Plasmid DNA encoding DAT was diluted serially from $0.01-100 \mathrm{pg}$, again in five series, each of which covered a 10 -fold range.

Amplifications were performed in a final volume of $20 \mu \mathrm{l}$ of a commercial reaction mixture (Roche) that contained TaqDNA polymerase, reaction buffer, dNTPs in which dTTP is replaced by dUTP, SYBR Green I dye, and $\mathrm{MgCl}_{2}$. The primers for the amplification of cDNA encoding $\beta$-actin, DAT, and TH were used at a final concentration of $0.3 \mu \mathrm{M}$. The final concentration of $\mathrm{MgCl}_{2}$ was $2.5 \mathrm{~mm}$ for the amplification of $\beta$-actin, $4 \mathrm{~mm}$ for that of DAT, and $3 \mathrm{~mm}$ for that of TH. To this mixture were added $2 \mu \mathrm{l}$ of either the serial diluted plasmid DNA (standards) or the cDNA prepared from tissue. The standards and the cDNA from tissues were subjected simultaneously to real-time PCR analysis in parallel capillary tubes. Within the instrument, the reaction mixture was first incubated for at $95^{\circ} \mathrm{C}$ for $30 \mathrm{sec}$ to denature the template DNA. Amplification was then performed for 40 cycles, each involving denaturation at $95^{\circ} \mathrm{C}$ for $0 \mathrm{sec}$, annealing for $5 \mathrm{sec}$ at $57^{\circ} \mathrm{C}$ (DAT and $\beta$-actin) or $58^{\circ} \mathrm{C}(\mathrm{TH})$, and elongation at $72^{\circ} \mathrm{C}$ for $21 \mathrm{sec}(\mathrm{DAT}), 14 \mathrm{sec}(\mathrm{TH})$, or $24 \mathrm{sec}(\beta$-actin). The appearance of double-stranded DNA was quantified by measuring the fluorescence of SYBR Green after each step of elongation. A melting point analysis was finally performed to improve the sensitivity and specificity of amplification reactions detected with the SYBR Green I dye; samples were incubated at $95^{\circ} \mathrm{C}$ for $0 \mathrm{sec}$, at $67^{\circ} \mathrm{C}$ for $15 \mathrm{sec}$, and then from 67 to $95^{\circ} \mathrm{C}$ with a transition rate of $0.2^{\circ} \mathrm{C} / \mathrm{sec}$. Data were analyzed with computer assistance using the LightCycler software.

Immunoprecipitation. Samples containing $200 \mu \mathrm{g}$ of protein from mouse brain, stomach, duodenum, ileum, and proximal and distal colon were removed, and $10 \mu$ l of goat anti-DAT antibody (Research Diagnostics Inc., Flanders, NJ) was added in a total volume of $50 \mu \mathrm{l}$. After incubation at $4^{\circ} \mathrm{C}$ overnight, $20 \mu$ l of washed UltraLink Immobilized Protein A/G (Pierce, Rockford, IL) was added, followed by incubation at $4^{\circ} \mathrm{C}$ with gentle agitation overnight. The reaction mixture was washed and centrifuged at 2,000 $\times g$ for $2 \mathrm{~min}$, and the supernatant was removed for DAT Western blotting.

Gel electrophoresis and immunoblotting. Tissue was harvested from mouse brain, stomach, duodenum, ileum, and proximal and distal colon, washed with PBS, and homogenized in $300 \mu \mathrm{l}$ of $50 \mathrm{~mm}$ Tris buffer, $\mathrm{pH}$ 7.4, containing EDTA (1.0 mM), EGTA (2.0 mM), PMSF (1.0 mM), aprotinin $(100 \mu \mathrm{g} / \mathrm{ml})$, and leupeptin $(100 \mu \mathrm{g} / \mathrm{ml})$. The homogenate was centrifuged at $10,000 \times g$ for $30 \mathrm{~min}$ at $4^{\circ} \mathrm{C}$ to separate a membrane fraction (pellet) from the cytosol. The pellet was solubilized in the same buffer containing Triton X-100 (1.0\%). Proteins (50 $\mu \mathrm{g})$ were separated by $8.5 \%$ SDS-PAGE. After separation, the proteins were electroblotted onto polyvinylidene difluride membranes and immersed in blocking buffer containing 5\% nonfat dry milk in TBS for $30 \mathrm{~min}$ at room temperature. The blot was washed with TBS containing $0.05 \%$ Tween 20 (TBST) and finally incubated overnight at $4^{\circ} \mathrm{C}$ with polyclonal primary antibodies to TH, DAT, or actin (Table 2) (diluted 1:1000 in 3\% nonfat dry milk). After washing in 
Table 2. Primary antibodies

\begin{tabular}{llllll}
\hline & & Dilution & & \\
Antigen & Antibody & Immunocytochemistry & Western blot & & Source \\
\hline Actin & Rabbit polyclonal & $\mathrm{N} / \mathrm{A}$ & $1: 1000$ & Sigma & Shanavas et al. (1996) \\
DA & Mouse monoclonal & $1: 1600$ & $\mathrm{~N} / \mathrm{A}$ & Chemicon (Temecula, CA) & Singaram et al. (1995) \\
DAT & Rabbit polyclonal & $1: 400$ & $1: 1000$ & Chemicon & Mitsuma et al. (1998), Lee et al. (1999) \\
Hu & Human & $1: 1500$ & $\mathrm{~N} / \mathrm{A}$ & Molecular Probes & Marusich et al. (1994) \\
TH & Rabbit & N/A & $1: 1000$ & Protos Biotech (New York, NY) & Pickel et al. (1980) \\
TH & Sheep polyclonal & $1: 800$ & $\mathrm{~N} / \mathrm{A}$ & Chemicon & Li et al. (1998), Young et al. (1999) \\
\hline
\end{tabular}

N/A, Not applicable.

TBST, the blot was incubated with goat HRP-labeled secondary antibodies to rabbit IgG (Vector Laboratories, Burlingame, CA) for $1 \mathrm{hr}$ at room temperature. The blot was washed with TBST and developed with a chemiluminescent substrate (Pierce, Rockford, IL).

Extrinsic denervation. The extrinsic innervation was ablated in segments of small intestine in 10 mice. The animals were anesthetized with a subcutaneous injection of a mixture of ketamine $(90 \mathrm{mg} / \mathrm{kg})$ and xylazine $(5 \mathrm{mg} / \mathrm{kg})$. The depth of anesthesia was monitored by checking the withdrawal reflex evoked by gentle squeezing of a toe with a pair of forceps. The surgical procedure used for denervation was similar to that used previously in the guinea pig small intestine (Li et al., 1998; Pan and Gershon, 2000). Two loops of intestine were denervated in each animal. For each denervation, a loop of ileum supplied by a single mesenteric artery and its branches was selected. On the mesenteric artery, the vessel was manipulated at a site that was $2-3 \mathrm{~cm}$ distant from the intestinal wall. All of the nerve fiber bundles at this site that could be seen to follow the mesenteric artery and vein that supplied the loop of the bowel were stripped away using fine forceps under microscopic control. To ablate any nerve fibers that were not severed by this procedure, the pair of vessels on the operation site were painted with a small amount of $80 \%$ phenol in distilled water, which was applied by a small swab under microscopic control. The excess phenol was then washed away thoroughly with $0.9 \% \mathrm{NaCl}$. The denervated region of the gut was marked by a loose ligature placed around its vascular supply, the bowel was returned to the abdominal cavity, and the abdomen was closed. After surgery, pain was minimized by the subcutaneous administration of buprenorphine (1 mg/ $\mathrm{kg}$ ). The animals were then allowed to recover from anesthesia and given ad libitum access to food and water. The mice were killed by $\mathrm{CO}_{2}$ inhalation 1 week after surgery. The two denervated loops of ileum and a single loop of normal small intestine (as control) were removed from each animal and analyzed by RT-PCR and immunocytochemistry. The sympathetic innervation of the gut was used as marker of the extrinsic innervation and was assessed to evaluate the extent of denervation. TH was demonstrated immunohistochemically to visualize the characteristic network of sympathetic terminals in the enteric plexuses. The denervated and control loops of gut were each divided into two equal pieces. One piece of tissue was used for RNA isolation and the other part for immunocytochemistry.

Immunocytochemistry. Segments of ileum and colon of mice and guinea pigs were collected in PBS, to which the muscle relaxant nicardipine was added to prevent spasm $\left(10^{-6} \mathrm{M}\right.$; Sigma, St. Louis, MO). Preparations were cut open along the mesenteric border, and the contents were flushed out with PBS. If whole mounts were to be prepared, the tissue was pinned flat on balsa wood with the mucosal surface facing down and stretched tautly. Specimens were fixed for $2 \mathrm{hr}$ at room temperature with $4 \%$ formaldehye (from paraformaldehyde; $\mathrm{pH} 7.4$ ) and washed with PBS three times for $10 \mathrm{~min}$. Laminar preparations of the longitudinal muscle with attached myenteric plexus (LM-MP) and of the submucosa were obtained by dissection. Tissue to be sectioned was not stretched and was cryoprotected by infiltration with $30 \%$ sucrose in PBS containing $0.1 \%$ sodium azide overnight at $4^{\circ} \mathrm{C}$. The preparations were embedded in optimal cutting temperature compound (Tissue Tek, Elkhart, IN) and cut at $10 \mu \mathrm{m}$ with a cryostat microtome. Slides were air dried for $1 \mathrm{hr}$ at room temperature. For immunostaining, specimens were permeabilized by incubation with $1 \%$ Triton X100 in PBS containing $10 \%$ normal rabbit, goat, or lamb serum (depending on the host species used to generate secondary antibodies, to block nonspecific stain- ing) for $30 \mathrm{~min}$ at room temperature. Tissues were then incubated overnight with primary antibodies (Table 2) at room temperature. After being washed in PBS three times for 10 min, the tissue was incubated with appropriate affinity-purified species-specific secondary antibodies for 1-2 $\mathrm{hr}$ at room temperature. To demonstrate the immunoreactivity of $\mathrm{DA}$, the monoamine oxidase (MAO) inhibitor pargyline was injected intraperitoneally $(100 \mu \mathrm{g} / \mathrm{kg})$ in mice or guinea pigs $30 \mathrm{~min}$ before the animals were killed (Costa and Furness, 1971) or added to the medium $(100 \mathrm{ng} / \mathrm{ml})$ of cultured myenteric neurons $1 \mathrm{hr}$ before fixation. A commercial kit (Iso-IHC, Mouse on Mouse kit; InnoGenex, San Ramon, $\mathrm{CA}$ ), which permits the use of murine antibodies to immunostain mouse tissue, was used to demonstrate DA immunoreactivity in mouse gut. The working concentrations of the secondary antibodies used for immunofluorescence were: biotin-labeled goat anti-human (Molecular Probes, Eugene, OR), goat anti-rabbit Alexa 594 (1:400; Molecular Probes), swine anti-sheep FITC (1:50; ICN Immuno Biologicals, Lisle, IL), biotinlabeled goat anti-mouse IgG (1:400; Kirkegaard \& Perry Laboratories, Gaithersburg, MD), Alexa 350-labeled avidin (Molecular Probes), and FITC-labeled streptavidin (1:200; Vector Laboratories).

HPLC analysis of DA and DOPAC. Extrinsically denervated and control loops of ileum ( $0.5 \mathrm{gm}$, wet weight) were removed from adult CD-1 mice and homogenized in $0.5 \mathrm{ml} 0.4 \mathrm{M}$ perchloric acid $\left(\mathrm{HClO}_{4}\right)$. The homogenate was then centrifuged at $11,000 \times g$ for $10 \mathrm{~min}$ at $4^{\circ} \mathrm{C}$. The resulting supernatant was transferred to fresh microcentrifuge tubes and stored at $-80^{\circ} \mathrm{C}$. The supernatants were used for the assay of DA and DOPAC by HPLC (Waters Associates, Miford, MA) with electrochemical detection (Tamir et al., 1994; Liu et al., 2000).

Myenteric ganglion isolation. The ganglia of guinea pig ileum were isolated as described previously (Chen et al., 2003). Briefly, the whole length of ileum was collected in ice-cold Krebs solution. After the gut contents were washed out with Krebs solution, the ileum was kept in ice-cold MEM (Invitrogen, Carlsbad, CA) with 25 mM HEPES (Sigma). The LM-MP was then dissected mechanically from the bowel and incubated at $37^{\circ} \mathrm{C}$ for $1-2 \mathrm{hr}$ in MEM, to which $1 \mathrm{mg} / \mathrm{ml}$ collagenase A (Boehringer Mannheim, Indianapolis, IN) and $1 \mathrm{mg} / \mathrm{ml}$ DNase I (Boehringer Mannheim) had been added. Individual myenteric ganglia were collected under microscopic control. Selected ganglia were plated in 2-well chamber slides that had been coated previously with poly-D-lysine $(10 \mathrm{mg} / \mathrm{ml})$ and mouse laminin $(10 \mathrm{mg} / \mathrm{ml})$ and cultured in a medium consisting of DMEM-F12 (Invitrogen, Gaithersburg, MD) supplemented with 2\% FBS (Invitrogen), penicillin-streptomycin (1\%), gentamycin $(100 \mathrm{mg} / \mathrm{ml}$; Sigma), and fungizone $(5.25 \mathrm{mg} / \mathrm{ml}$; Invitrogen $)$. Mitotic inhibitors [5-fluoro-20-deoxyuridine (10 mM), uridine (10 mM), and cytosine $\beta$-D-arabinofuranoside ( $1 \mathrm{~mm}$ ); Sigma] were added to prevent the growth of non-neuronal cells. After 1 week in vitro, cultures were rinsed with PBS and fixed in $4 \%$ formaldehyde (from paraformaldehyde; $\mathrm{pH}$ 7.4) for $30 \mathrm{~min}$ and processed for immunocytochemistry.

\section{Results}

\section{Transcripts encoding TH are found in the mouse gut}

RT-PCR was used to determine whether RNA extracted from the stomach, duodenum, ileum, and proximal and distal colon contains transcripts encoding TH. The brain was studied at the same time as a positive control. mRNA encoding TH was investigated as a marker for intrinsic catecholaminergic neurons. Noradren- 


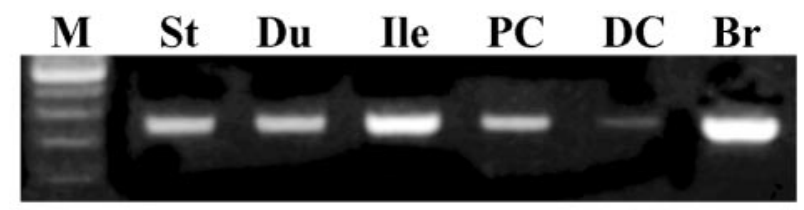

A

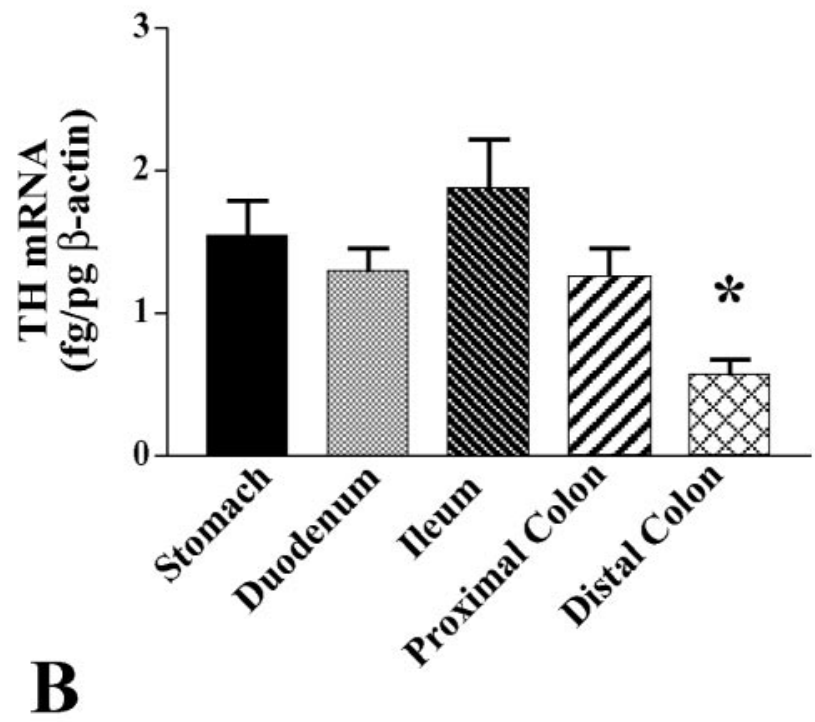

Figure 1. Transcripts encoding TH are expressed in the mouse gut. A, RNA was extracted from adult mouse stomach (St), duodenum (Du), ileum (Ile), proximal colon (PC), distal colon $(\mathrm{DC})$, and brain $(\mathrm{Br})$, which served as a positive control, and analyzed by RT-PCR. M, 100 bp size markers. $B$, The abundance of transcripts encoding TH in each region of the bowel relative to those encoding $\beta$-actin were determined by real-time PCR. The abundance of transcripts encoding $\mathrm{TH}$ is significantly lower in the distal colon than in other regions of the bowel ( $\left.{ }^{*} p<0.02\right)$.

ergic and dopaminergic neurons both contain TH; however, the murine bowel does not contain intrinsic noradrenergic neurons. The noradrenergic components of the ENS are extrinsic axons projecting from sympathetic ganglia (Costa and Furness, 1984; Keast et al., 1984; Wood, 1999). Although noradrenergic axons contain TH protein transported from cell bodies, they would not be expected to express mRNA encoding TH. Transcripts encoding $\mathrm{TH}$ were found in each of the examined regions of the bowel and in the brain (Fig. 1A). mRNA encoding TH was quantified in the different regions of the gut by using real-time PCR to amplify cDNA. The abundance of mRNAs encoding $\beta$-actin and TH was measured in five regions of the bowel (stomach, duodenum, ileum, and proximal and distal colon) in each of the five mice. The relative quantity of mRNA encoding TH was normalized to that encoding $\beta$-actin in each region (Fig. $1 B$ ). The relative abundance of mRNA encoding $\mathrm{TH}$ did not differ statistically in samples of the stomach, duodenum, ileum, and proximal colon; however, each of these regions contained significantly more mRNA encoding $\mathrm{TH}$ than did the distal colon $(p<0.02)$. Because the mature gut lacks noradrenergic neurons, these data are, by elimination, consistent with the idea that a subset of intrinsic cells is dopaminergic.

\section{DAT is expressed in the mouse gut}

The expression of transcripts encoding DAT was investigated in the murine bowel because DAT is normally restricted in its expression to dopaminergic neurons (Iversen, 2000). The gut
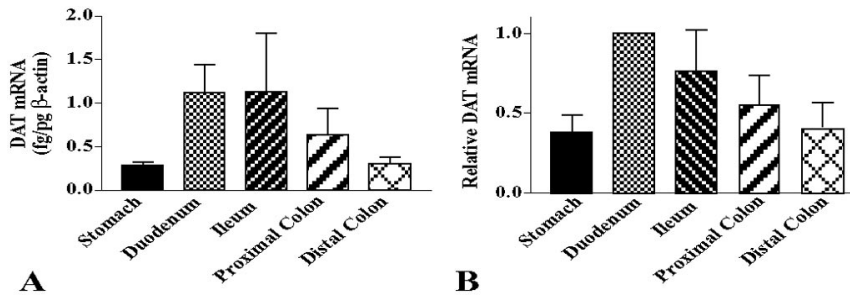

Figure 2. Transcripts encoding DAT are expressed in the mouse gut. $A$, The abundance of transcripts encoding DAT in each region of the bowel relative to those encoding $\beta$-actin were determined by real-time $P C R$. $B$, The relative abundance of transcripts encoding DAT in each region of the bowel were normalized to that in the duodenum of each animal. The abundance of transcripts encoding DAT is significantly higher in the duodenum than in the stomach or distal colon $\left({ }^{*} p<0.05\right)$.

would, therefore, be expected to express DAT if it contains intrinsic dopaminergic neurons. Prior studies, using RT-PCR, have demonstrated the presence of transcripts encoding DAT in the mouse ileum and colon (Chen et al., 2001). These transcripts were found to be absent in transgenic $\mathrm{C} 57 \mathrm{BL} / 6$ mice that lack the gene encoding DAT; however, they were found in transgenic C57BL/ 6 mice that lack the serotonin transporter. We confirmed these observations in the stomach, duodenum, ileum, and proximal and distal colon of CD-1 mice. By using real-time PCR, we then evaluated quantitatively the relative expression of DAT in the stomach, duodenum, ileum, and proximal and distal colon of CD-1 mice (Fig. 2). mRNA encoding DAT was normalized to that of $\beta$-actin in each sample (Fig. $2 A$ ). Because considerable variation was encountered between animals, the values obtained in each region of the bowel were further normalized to those obtained in the duodenum of the same animal to evaluate the relative regional abundance of transcripts encoding DAT (Fig. $2 B$ ). The expression of DAT was found to be significantly higher in the duodenum than in the stomach or distal colon $(p<0.05)$. The relative abundance of mRNA encoding DAT in the intestine, thus, resembled that encoding $\mathrm{TH}$ in that it was least abundant in the distal colon. The presence in the gut of transcripts encoding DAT is consistent with the idea that intrinsic dopaminergic neurons exist in the bowel; however, the abundance of transcripts encoding DAT does not precisely parallel that of transcripts encoding $\mathrm{TH}$.

To verify that DAT protein, as well as transcripts, are expressed in the bowel, the regional distribution of DAT was analyzed by immunoblotting in the stomach, duodenum, ileum, and proximal and distal colon. TH was studied for comparison, although $\mathrm{TH}$ protein in extracts of gut could originate in sympathetic nerves as well as in intrinsic neurons. The brain served as a positive control, and actin was demonstrated as a loading control for the gels. Enteric DAT was concentrated by immunoprecipitation before its analysis by immunoblotting. DAT protein was detected in the stomach, duodenum, ileum, and proximal and distal colon (Fig. 3).

\section{Coincident expression of TH and DAT immunoreactivities occurs in the ENS}

DAT-immunoreactive neurons have been reported previously to be present in both the submucosal and myenteric plexuses of the mouse gut (Chen et al., 2001); however, whether or not the DATimmunoreactive neurons in the bowel also contain $\mathrm{TH}$, as would be expected of dopaminergic neurons, was not determined. We, therefore, investigated the extent to which the location of DAT immunoreactivity is coincident with that of $\mathrm{TH}$ in the murine ENS. The presence of DAT-immunoeactive neurons in both enteric plexuses was confirmed. DAT-immunoreactive nerve cell 


\section{Br St Du Ile PC DC}

DAT

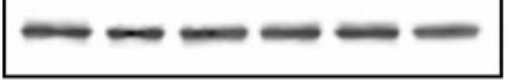

$80 \mathrm{kDa}$

TH

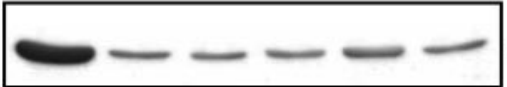

$56 \mathrm{kDa}$

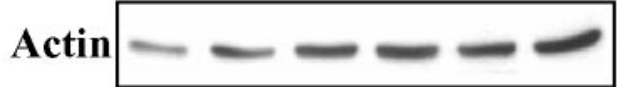

$42 \mathrm{kDa}$

Figure 3. DAT and TH immunoreactivities are present in the mouse gut. $A$, The distributions of DAT and TH proteins in the stomach (St), duodenum (Du), ileum (lle), proximal colon (PC), distal colon (DC), and brain (Br) (positive control) were analyzed by immunoblotting. Enteric DAT was concentrated by immunoprecipitation before immunoblotting. Actin was analyzed as a loading control.

bodies were found to be more abundant in the submucosal than the myenteric plexus in both the ileum (Fig. $4 B, E$ ) and the colon (Fig. $4 G, I$ ). Varicose terminal axons were also DAT immunoreactive in both plexuses. DAT immunoreactivity coincided with that of TH in the cell bodies of many submucosal neurons and a smaller subset of myenteric neurons in both the ileum (Fig. $4 B-F$ ) and colon (Fig. 4G-J). Especially in the myenteric plexus, the number of varicose $\mathrm{TH}$-immunoreactive axons exceeded that of DAT-immunoreactive axons, although the two markers also appeared to be colocalized in a large subset. Expression of DAT is thought to be restricted to dopaminergic neurons (Lorang et al., 1994; Ciliax et al., 1999; Holzschuh et al., 2001). DAT expression was investigated immunocytochemically in the celiac ganglion to confirm whether or not pervertebral sympathetic neurons that project to the gut are DAT immunoreactive. No DAT immunoreactivity was detected in the sympathetic neurons of the celiac ganglion (Fig. $4 \mathrm{~K}$ ), although these noradrenergic neurons were all TH immunoreactive (Fig. $4 L$ ). Because sympathetic neurons, thus, express TH but not DAT, the axons in the gut that contained $\mathrm{TH}$, but not DAT, immunoreactivity were probably sympathetic. The enteric TH-immunoreactive cell bodies that also contained DAT, however, were clearly intrinsic and, thus, good candidates to be intrinsic dopaminergic neurons. Another subset of DATimmunoreactive nerve cell bodies was observed in the myenteric plexus, however, that contained no detectable $\mathrm{TH}$ immunoreactivity (Fig. $4 I, J$ ). The relative numbers of DAT- and THimmunoreactive neurons were quantified in the myenteric and submucosal plexuses of the mouse ileum. Approximately $67 \%$ of DAT-immunoreactive myenteric neurons and $64 \%$ of DATimmunoreactive submucosal neurons were found to contain $\mathrm{TH}$ immunoreactivity (Table 3 ), and $\sim 58 \%$ of $\mathrm{TH}$-immunoreactive myenteric neurons and $65 \%$ of $\mathrm{TH}$-immunoreactive submucosal neurons were found to contain DAT immunoreactivity (Table 3). The neuronal marker, $\mathrm{Hu}$, was used to demonstrate immunocytochemically all enteric neurons in triply labeled preparations to quantify the proportion of enteric neurons that are DAT or $\mathrm{TH}$ immunoreactive. DAT-immunoreactive neurons were found to constitute $\sim 10 \%$ of myenteric and $12 \%$ of submucosal neurons, whereas, $\mathrm{TH}$-immunoreactive neurons constituted $~ 9 \%$ of myenteric and $13 \%$ of submucosal neurons (Table 3 ). DAT immunoreactivity was also examined in cryostat sections of the bowel to determine the distribution of DAT-immunoreactive fibers in
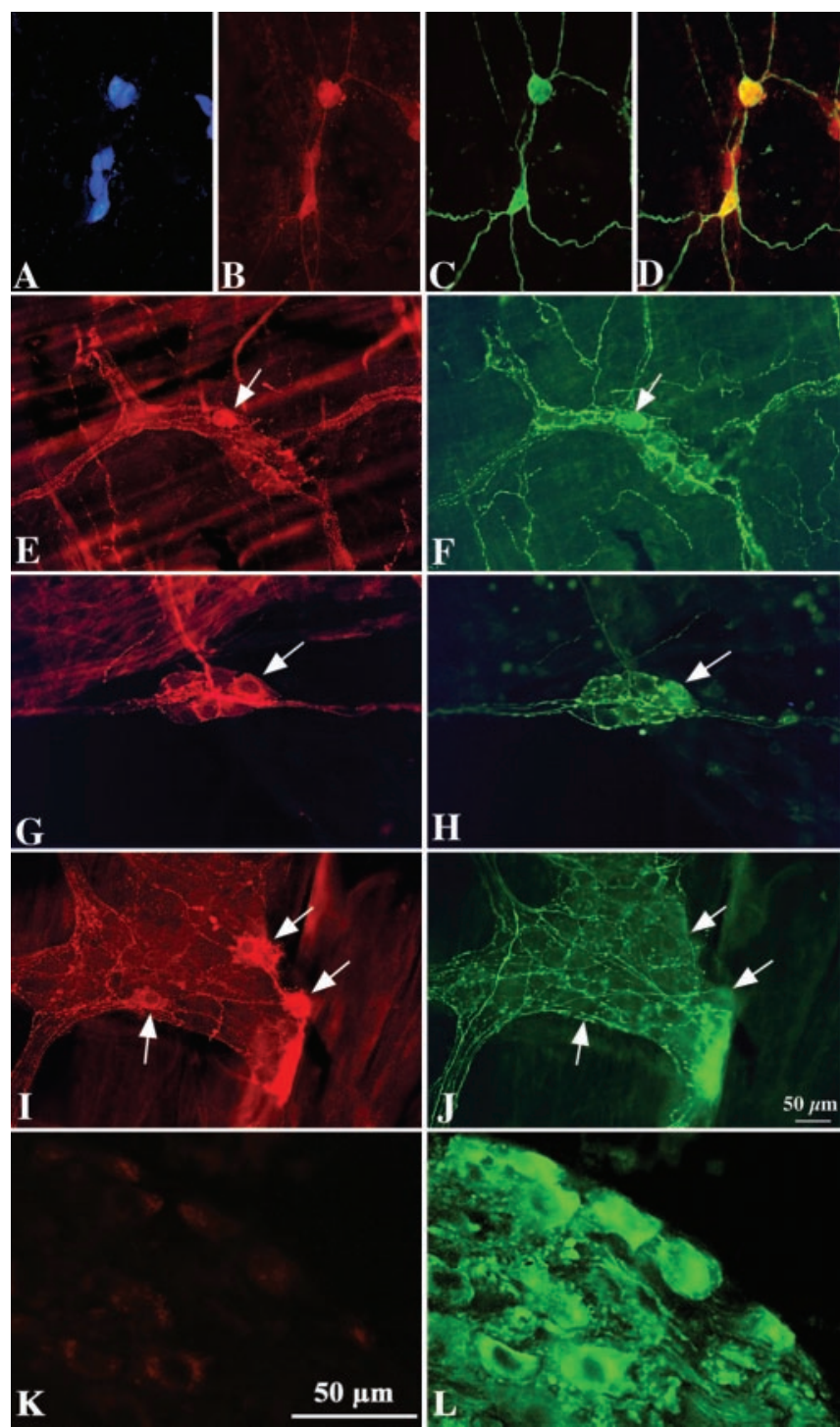

Figure 4. DAT and TH immunoreactivities are partially coincident in the mouse ileum and colon; sympathetic neurons of the celiac ganglion are TH immunoreactive but not DAT immunoreactive. Double-label or triple immunocytochemistry illuminated to reveal $\mathrm{Hu}$ ( $A$; blue fluorescence), DAT ( $B, E, G, I, K$; red fluorescence), and $\mathrm{TH}(C, F, H, J, L$; green fluorescence) immunoreactivities in the same fields in submucosal and myenteric plexuses of the ileum and colon. Coincident labeling is apparent in the yellow cells in the merged image of TH and DAT immunoreactivities $(D)$. The immunoreactivity of Hu was studied as a neuronal marker. $A-D$, Submucosal plexus of the ileum. $E, F$, Myenteric plexus of the ileum. $G, H$, Submucosal plexus of the colon. I, J, Myenteric plexus of the colon. K, L, Celiac (prevertebral sympathetic) ganglion. Arrows indicate the locations of individual cells in paired figures. Scale bar, $50 \mu \mathrm{m}$.

Table 3. Colocalization of TH and DAT immunoreactivities in the ENS

\begin{tabular}{lcl}
\hline Mouse ileum & $\begin{array}{l}\text { Myenteric } \\
\text { plexus }\end{array}$ & $\begin{array}{l}\text { Submucosal } \\
\text { plexus }\end{array}$ \\
\hline TH/100 DAT neurons & $67 \pm 9 \%$ & $64 \pm 11 \%$ \\
TH/100 neurons (total = Hu immunoreactive) & $9 \pm 3 \%$ & $13 \pm 1 \%$ \\
DAT/100 TH neurons & $58 \pm 18 \%$ & $65 \pm 2 \%$ \\
DAT/100 neurons (total = Hu immunoreactive) & $10 \pm 4 \%$ & $12 \pm 4 \%$ \\
\hline
\end{tabular}

Data are expressed as means \pm SE. Two hundred neurons were counted in each of three mice.

layers of the gut. No fibers were detected in the muscle layers of the gut or in the mucosa (data not shown). These observations suggest that DAT-immunoreactive axons are confined to the enteric plexuses and that their targets are, thus, likely to be other enteric neurons or axons. 
DA

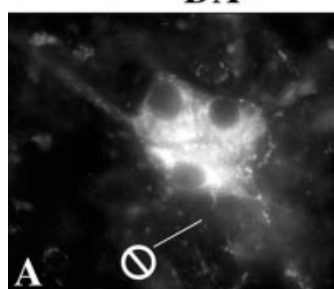

DAT

SmP

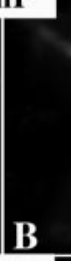

\section{DAT}

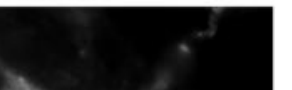

coincident in the cell bodies of the cultured myenteric neurons (Fig. 6). These observations suggest that DA is located in enteric neurons that express DAT and that all enteric DAT is located in intrinsic neurons, in these preparations.

\section{Extrinsic denervation increases the number of detectable TH-immunoreactive neurons in the submucosa plexus}

The mouse ileum was subjected to extrinsic denervation to verify that the cells that express TH and DAT are intrinsic cells of the bowel wall and to determine whether the expression of $\mathrm{TH}$ by intrinsic neurons is altered by the loss of an extrinsic source of TH. Extrinsic denervation was achieved by compressing perivascular nerves in mesenteric arcades and confirmed by examining the distribution of sympathetic axons in the gut wall. After denervation, both myenteric and submucosal neuronal cell bodies continued to be both TH and DAT immunoreactive (Fig. 7), although the numbers of such cells were far greater in the submucosal than the myenteric plexus. In contrast, the $\mathrm{TH}$-immunoreactive varicose axons, which form a dense network in the enteric plexuses of control preparations (Fig. $7 A, E$ ), disappeared after denervation (Fig. $7 C, D, F)$. Partial denervation was evident in the tissue at the border between fully denervated and normally innervated segments of tissue, forming an easily recognized transitional zone that permitted the precise demarcation of denervated and innervated bowel (Fig. 7B). DAT-immunoreactive cells also persisted after extrinsic denervation in both the myenteric (Fig. 7G) and submucosal plexuses (Fig. $7 H$ ). Surprisingly, TH-immunoreactive nerve cell bodies not only persisted after denervation of the gut, but their numbers increased greatly (Fig. 7, compare E,F). The number of $\mathrm{TH}$-immunoreactive neurons in extrinsically denervated segments of submucosal plexus was almost threefold that of the normally innervated segments of the same bowel (Table 4). In contrast, the total numbers of neurons (measured either per ganglion or per unit area of tissue) were unchanged by denervation. These data suggest that the increase in number of TH-immunoreactive neurons after denervation is unlikely to be attributable to the generation of new neurons from stem cells and is probably the result of increased $\mathrm{TH}$ expression by existing neurons, which increases the number of cells that contain enough TH protein to be immunocytochemically detectable.

\section{Coincident expression of DA and DAT immunoreactivities occurs in the ENS}

Nerve terminals containing DA immunoreactivity have been reported previously to contact choline acetyltransferaseimmunoreactive neurons in the guinea pig stomach (Shichijo et al., 1997), and DA-immunoreactive neurons have been observed in the human (Singaram et al., 1995), but not the mouse, gut. The location of DA immunoreactivity was, therefore, investigated in both the mouse and guinea pig bowel, and the extent to which DA immunoreactivity was coincident with that of DAT was also studied. The guinea pig was examined because the guinea pig ENS has been more thoroughly characterized than that of any other species. In addition, it is relatively easy to isolate and culture myenteric ganglia from guinea pigs to obtain ganglia that are free of extrinsic nerve fibers. DA-immunoreactive nerve cell bodies were found in both the submucosal and myenteric plexuses of the ileum in both mice (Fig. 5A-D) and guinea pigs (Fig. 5E-H). DA and DAT were found to be fully colocalized in neuronal perikaya in both species (over 300 neurons were analyzed in each). To be absolutely certain that the neurons that coexpressed DA and DAT were intrinsic, myenteric ganglia were isolated from the guinea pig ileum and cultured for 1 week before examination. Extrinsic elements of the ENS degenerate under these conditions. DA and DAT immunoreactivities were also found to be completely

\section{Extrinsic denervation increases the enteric expression of mRNA encoding TH and DAT}

The denervation-induced increase in neurons containing immunocytochemically detectable $\mathrm{TH}$ could be explained by a corresponding increase in denervation-induced TH transcription. Alternatively, denervation could unmask a previously sequestered source of preexistent $\mathrm{TH}$. Transcripts encoding $\mathrm{TH}$ were, thus, quantified by using real-time RT-PCR in extrinsically denervated and innervated segments of the bowel. Transcripts encoding DAT were also quantified to determine whether changes, if any, were restricted to transcription of $\mathrm{TH}$ or whether they extended also to other molecules involved in dopaminergic signaling. Extrinsic denervation of the mouse ileum was found to increase both the amount of mRNA encoding TH and that encoding DAT. RNA was extracted from the denervated and innervated segments of the bowel in eight animals, and real-time PCR was used for quantitation. The normally innervated segment of gut served as a control for the effect of extrinsic denervation in the same animal, and measured quantities of mRNA were normalized to that of $\beta$-actin in the same samples. The differences, compared by means of a paired $t$ test, were significant both for mRNA encoding $\mathrm{TH}$ (control, $0.17 \pm 0.05$; denervated, $0.45 \pm 0.06 ; p<0.03$ ) and 
DAT (control, $0.040 \pm 0.005$; denervated, $0.070 \pm 0.008 ; p<0.02$ ). These data are consistent with the idea that intrinsic enteric neurons that express both $\mathrm{TH}$ and DAT respond to extrinsic denervation by increasing transcription of molecules associated with neurotransmitter biosynthesis and uptake. Conceivably, this upregulation is a compensatory mechanism that helps to mitigate the loss of NE.

\section{Effects of extrinsic denervation on enteric DA and DOPAC}

The increased transcription of $\mathrm{TH}$ and DAT in the denervated bowel suggests that the content, turnover, or both of DA should rise in the affected region. The levels of DA and its specific metabolite, DOPAC, were, therefore, measured in paired segments of innervated and denervated ileum. The pairs were obtained from the same bowel; however, they were taken from segments of gut that were vascularized by different, nonoverlapping vascular arcades, separated from each other by $\sim 5 \mathrm{~cm}$ of tissue. Levels of DOPAC and DA were measured in denervated and innervated segments of the bowel in 10 animals. The normally innervated segment of gut served as a control for the effect of extrinsic denervation in the same animal. Extrinsic denervation was found to significantly increase the tissue content of DOPAC in the ileum (control, $0.45 \pm 0.12 \mathrm{pmol} / \mathrm{mg}$; denervated, $0.68 \pm 0.17 ; p<0.05$ ); however, the increase in the concentration of DA in the same denervated segments of the bowel did not achieve significance (control, $0.16 \pm 0.03$; denervated, $0.19 \pm 0.13$ ). These observations confirm that the majority of the DA in the bowel is not of sympathetic origin because the concentration of DA does not decrease when the sympathetic nerves degenerate. The increased tissue content of DOPAC in the extrinsically denervated bowel is consistent with the idea that the turnover of DA increases after denervation, possibly because dopaminergic neurons become more active; however, as usually occurs when catecholaminergic neurons are stimulated, an increase in transmitter biosynthesis compensates for the stimulation-induced transmitter release to maintain near constancy in the stores of the transmitter (Weiner, 1970; Molinoff and Axelrod, 1971; Iuvone et al., 1978).

TH neurons are present in transgenic mice that lack mash-1 $\mathrm{TH}$ is expressed in catecholaminergic cells in developing ENS during fetal life (Cochard et al., 1978; Teitelman et al., 1978, 1981; Jonakait et al., 1979; Gershon et al., 1984b). Expression of TH and other catecholamine-related molecules disappears from the rat gut at E15 (Baetge et al., 1990a) and from the mouse gut at E14 (Baetge et al., 1990b). These molecules disappear because the TC cells that express them are proliferating neuronal precursors that give rise to terminally differentiated neurons, such as those that express 5-HT (Teitelman et al., 1981; Gershon et al., 1984a; Baetge et al., 1990a) and nitric oxide synthase (NOS) (Branchek and Gershon, 1989; Young et al., 1999), which are not catecholaminergic. TC cells express the transcription factor Mash-1 and fail to develop when mash-1 is deleted (Blaugrund et al., 1996); however, the possibility that a second population of catecholaminergic cells develops in the gut later in ontogeny, from Mash-1-independent precursors, after the initial Mash-1dependent population no longer expresses $\mathrm{TH}$, has not previously been investigated. Because catecholaminergic cells are present in fetal life, we tested the hypothesis that the $\mathrm{TH}$ -
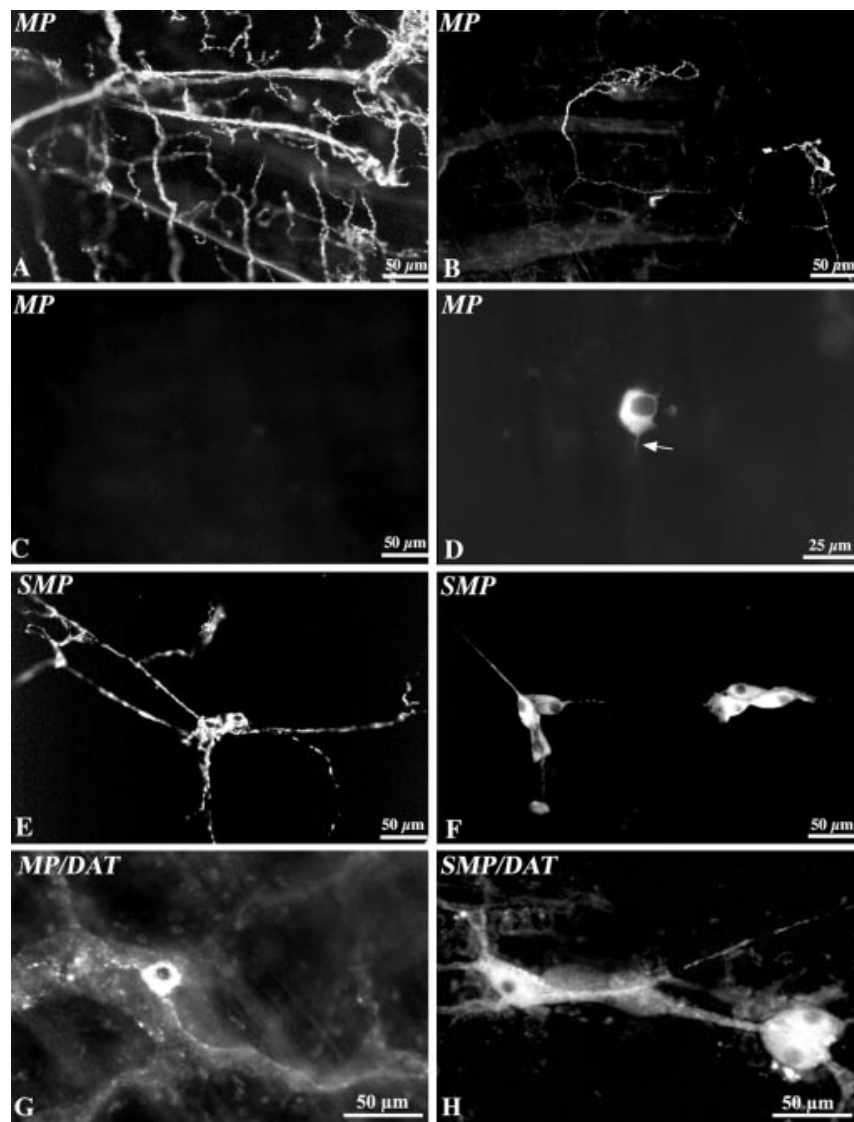

Figure 7. Extrinsic denervation confirms that myenteric and submucosal THimmunoreactive neurons are intrinsic. TH immunoreactivity demonstrated in laminar preparations of myenteric and submucosal plexuses. $A$, Myenteric plexus control. The sympathetic axons are characterized by large varicosities and are very abundant. $B$, Myenteric plexus at the border between denervated and innervated segments. A small number of varicose sympathetic axons remain in irregular clusters. C, Myenteric plexus within the denervated segment. No TH-immunoreactive sympathetic axons remain. $D$, Myenteric plexus within the denervated segment. An intrinsic TH-immunoreactive neuron can be discerned. Note the very fine axon extending from it. $E$, Submucosal plexus control. Sympathetic axons are again characterized by large varicosities. F, Submucosal plexus within the denervated segment. Several intrinsic THimmunoreactive neurons can be discerned. Note their extension of fine nonvaricose axons. The varicose sympathetic axons are no longer visible. $G$, Myenteric plexus within the denervated segment showing DAT immunoreactivity. A DAT-immunoreactive neuron is apparent within a ganglion. $H$, Submucosal plexus within the denervated segment showing several DATimmunoreactive neurons in interconnected ganglia. Scale bars: $A-C, E-H, 50 \mu \mathrm{m} ; D, 25 \mu \mathrm{m}$.

expressing dopaminergic neurons of the mature bowel arise from TC cell precursors. The expression of TH was investigated by immunocytochemistry in the bowel of wild-type (mash-1+/+) and transgenic mice that lack Mash-1 (mash-1-/-). The gut was 
Table 4. Effect of extrinsic denervation on submucosa neurons

\begin{tabular}{lcc}
\hline Parameter measured & Innervated & Denervated \\
\hline TH/100 neurons (total = Hu immunoreactive) & $13 \pm 1$ & $34 \pm 3$ \\
Total neurons/100 ganglia & $305 \pm 5$ & $289 \pm 7$ \\
Neurons / $2 \mathrm{~mm}^{2}$ submucosal plexus & $147 \pm 26$ & $149 \pm 19$ \\
\hline
\end{tabular}

Data are expressed as means \pm SE $(n=3)$.

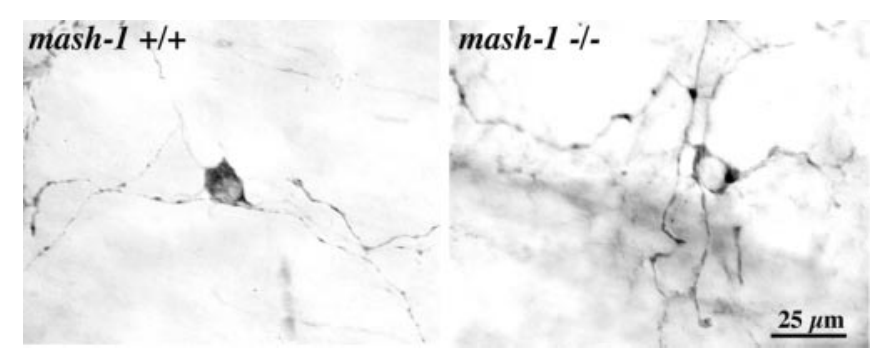

Figure 8. TH-immunoreactive neurons are present in the bowel of transgenic mice that lack mash-1.

studied in perinatal animals because mash-1-/- mice do not survive postnatally. Although TH disappears from the fetal mouse intestine by E14-E15 (Baetge and Gershon, 1989), a second late-arising population of $\mathrm{TH}$-immunoreactive neurons was found to be present in the gut of wild-type mice (data not shown). In contrast to TC cells, which are found in the outer gut mesenchyme, and external to the circular muscle when that layer develops, the late-arising $\mathrm{TH}$-immunoreactive cells were primarily submucosal in location. TH-immunoreactive neurons were found in the intestine both in perinatal mash $-1+/+(0.18$ cells $/$ $\mathrm{mm}^{2}$ ) and perinatal mash $1-/-$ mice $\left(2.1 \mathrm{cells} / \mathrm{mm}^{2}\right)$ (Fig. 8 ). These observations indicate that the hypothesis that $\mathrm{TC}$ cells give rise to the dopaminergic neurons of adults can be rejected. They also suggest that a second wave of catecholaminergic neurons, which is independent of mash-1 expression, arises perinatally. The apparent increase in packing density of $\mathrm{TH}$-immunoreactive cells in mash-1-/- mice is likely to reflect the absence in these animals of all of those neurons that are derived from TC cell precursors. The bowel of mice that lack mash-1 contains only Mash-1-independent neurons, such as those that contain calcitonin gene-related peptide, but not neurons that are Mash-1 dependent, such as those that contain 5-HT (Blaugrund et al., 1996).

\section{Discussion}

Observations made during the course of the present study strongly support the hypothesis that the gut contains intrinsic dopaminergic neurons. Transcripts encoding the critical biosynthetic enzyme TH are found in the bowel, and a subset of intrinsic enteric neurons is TH immunoreactive. The gut also contains mRNA encoding DAT and DAT-immunoreactive neurons. The immunoreactivities of TH and DAT colocalize in enteric neurons, which persist when enteric ganglia from the guinea pig intestine are cultured, confirming that these neurons are intrinsic. DA immunoreactivity is present in enteric neurons, colocalizes in subsets with the immunoreactivities of TH and DAT, and in cultured neurons, the immunoreactivity of DA is absolutely coincident with that of DAT. Neurons that contain TH and DAT can potentially obtain DA by synthesizing it from tyrosine or by taking it up from the ambient medium. TH is the rate-limiting enzyme in DA biosynthesis, but aromatic L-amino acid decarboxylase is also required to convert L-dihydroxyphenylalanine ( $\mathrm{L}-$ DOPA) to DA.
Intrinsic neurons of the bowel that contain aromatic L-amino acid decarboxylase have long been known to be present in the ENS. These cells, which were found to be more numerous in the submucosal than the myenteric plexus, were originally called "amine handling neurons" because they synthesize DA from L-DOPA and 5-HT from 5-hydroxytryptophan (Costa et al., 1976; Furness and Costa, 1978; Furness et al., 1980). The distribution of amine handling neurons (Furness and Costa, 1978) is similar to that of the TH-immunoreactive neurons of the mouse intestine. Because they are DA immunoreactive in the absence of pretreatment with exogenous L-DOPA or DA, the intrinsic neurons found in the current study to contain the immunoreactivities of TH and DAT probably also contain aromatic L-amino acid decarboxylase. These intrinsic TH-, DA-, and DAT-immunoreactive neurons are, thus, likely to have been included in, or identical to, the population of amine handling neurons described previously. Intrinsic enteric neurons, thus, contain DA, contain the enzymes needed to synthesize it from tyrosine, and can inactivate DA (by DAT-mediated reuptake) after its release from stimulated neurons. Given that DA is also released from stimulated enteric neurons (Shichijo et al., 1997) and exerts effects on enteric neurons (Hirst and Silinsky, 1975) and neurites that are identical pharmacologically to those of an endogenous transmitter (Kusunoki et al., 1985), DA fulfills the criteria necessary to identify it as an enteric neurotransmitter (Iversen, 1979).

In addition to the neurons in which the immunoreactivities of $\mathrm{TH}$ and DAT colocalize, the gut also contains a small number of neurons that contain the immunoreactivity of DAT, but not that of TH; moreover, the relative abundance of transcripts encoding $\mathrm{TH}$ and DAT is not identical in all regions of the bowel. It is possible that a subset of noncatecholaminergic enteric neurons contains DAT; however, this possibility is not supported by the observation that every neuron found in vitro to contain DAT also contains DA. Conceivably, the DA in some DAT-expressing neurons reflects the uptake of DA produced by another cell in the cultures. No DA was added to the incubation medium, however, and DA is highly unstable in solutions that lack antioxidants. It, thus, seems more likely that the DA immunoreactivity found in DAT-immunoreactive neurons in vitro reflects the biosynthesis of DA by these cells. Alternatively, DAT could be found in neurons that apparently lack $\mathrm{TH}$ if the level of $\mathrm{TH}$ were to vary according to physiological circumstances in individual neurons, so as to rise above or fall below the threshold necessary for immunocytochemical detection. If this alternative is correct, then the gut might contain a fixed number of potentially dopaminergic neurons (at least some of which are DAT immunoreactive) that is greater than the number that is demonstrated with antibodies to $\mathrm{TH}$. The number of neurons that are functionally dopaminergic may be submaximal until the bowel is stressed by circumstances that provoke the upregulation of $\mathrm{TH}$.

Extrinsic denervation may be an example of a stimulus that upregulates $\mathrm{TH}$ and other molecules related to dopaminergic mechanisms. Extrinsic denervation increases both the abundance of transcripts encoding both TH and DAT in the bowel and leads to a threefold increase in the numbers of demonstrable $\mathrm{TH}$-immunoreactive enteric neurons. These neurons, moreover, appear in the absence of a corresponding increase in the total numbers of neurons in either enteric plexus. The increment in TH-immunoreactive neurons, thus, appears to be the result of recruitment of existing neurons to the dopaminergic phenotype, rather than the de novo genesis of new neurons from stem cells, although stem cells do exist in the mature bowel (Bixby et al., 2002; Kruger et al., 2002).

The upregulation of TH and DAT induced by extrinsic dener- 
vation is not accompanied by an increase in the DA concentration of the intestine. Instead, extrinsic denervation leads to an increase in the concentration of DOPAC, the specific metabolite of DA. The persistence of DA and DOPAC in the extrinsically denervated bowel clearly establishes that sympathetic nerves are responsible neither for the bulk of the DA stored in the gut nor for its metabolism by MAO. In contrast, the increase in the metabolism of DA to DOPAC that occurs when sympathetic or other extrinsic nerves are absent is consistent with the idea that extrinsic denervation provokes an increase in the activity of intrinsic dopaminergic neurons. Release and DAT-mediated reuptake of DA by activated neurons would be expected to mobilize sequestered DA from storage vesicles and, thus, enhance its metabolism by promoting exposure of DA to mitochondrial MAO. Increased activity of dopaminergic neurons in other locations has also been found to be associated with increased biosynthesis of DA (Iuvone et al., 1978), which would account, in the ENS, for the extrinsic denervation-induced upregulation in transcription of $\mathrm{TH}$. Transmitter content normally remains relatively constant in catecholaminergic neurons, despite marked fluctuations in neuronal activity (Weiner, 1970; Molinoff and Axelrod, 1971).

It is not clear how extrinsic denervation increases dopaminergic activity in the ENS. Extrinsic sympathetic nerves are known to decrease the release of ACh from excitatory cholinergic nerve terminals via $\alpha$-2 adrenoceptors (Scheibner et al., 2002) and to evoke IPSPs in submucosal neurons (Wood, 1999). The effects of DA on enteric neurons have not been investigated thoroughly, but, like NE, DA is known to inhibit the release of ACh from stimulated enteric nerves (Kusunoki et al., 1985), and DA also mimics the effects on submucosal neurons of NE and sympathetic nerve stimulation (Hirst and Silinsky, 1975). The net effects on the ENS of DA released from intrinsic dopaminergic neurons and NE released from extrinsic sympathetic nerve terminals may, thus, be similar. If so, the upregulation of dopaminergic mechanisms might help to compensate for the loss of the extrinsic sympathetic innervation. In fact, a previous study noted that extrinsic denervation increases the intestinal content of aromatic amino acid decarboxylase and speculated that sympathetic nerves exert "some restraining influence" on the amine handling neurons that contain this enzyme (Mann et al., 1989). The mechanism that functionally couples the extrinsic sympathetic and intrinsic dopaminergic innervations of the bowel remains to be determined. Also remaining to be ascertained is the identity of inputs to enteric dopaminergic neurons, the neuroactive substances, if any, that are co-stored with DA, and the enteric circuits in which dopaminergic neurons function.

The development of enteric dopaminergic neurons is somewhat surprising in that they appear to arise independently of the catecholaminergic precursors that are found in the early fetal bowel. These TC precursors, which are mash-1 dependent, proliferate and characteristically give rise to terminally differentiated neurons that are born early in the ontogeny of the bowel, including those that contain 5-HT or NOS (Branchek and Gershon, 1989; Pham et al., 1991; Blaugrund et al., 1996; Young et al., 1999). Although TC cells express TH, they appear to contain NE rather than DA, and because they specifically take up ${ }^{3} \mathrm{H}-\mathrm{NE}$ (Gershon et al., 1984b), they evidently express the NE transporter rather than DAT. In contrast, dopaminergic neurons arise perinatally, which is relatively late in the development of the ENS (Pham et al., 1991), and like other late-developing neurons (Branchek and Gershon, 1989; Pham et al., 1991; Blaugrund et al., 1996; Young et al., 1999), dopaminergic neurons appear to be mash-1 independent. The function of the expression of cat- echolaminergic properties in enteric neuronal precursor cells has never been ascertained, although it might be related to a still-tobe-determined developmental role played by NE. Mice that lack TH (Thomas et al., 1995; Zhou et al., 1995) or DBH (Thomas et al., 1995) exhibit similar patterns of fetal lethality, whereas mice that lack DA, but not NE, are viable (Zhou and Palmiter, 1995). $\mathrm{NE}$, but not DA, is, thus, essential for viability in fetal mice (Thomas et al., 1995). The necessary role played by NE in fetal development is compatible with the possibility that NE exerts trophic effects during development (Zhou et al., 1995). If so, then NE from TC cells could be an enteric trophic factor; however, fetal NE may be required simply to maintain heart rate during periods of stress (Portbury et al., 2003). Whatever the role of NE from TC cells may be, neither NE nor TC cells or their progeny are needed for the development of enteric dopaminergic neurons, which develop normally in the TC cell-deficient bowel of mash-1-/- mice.

\section{References}

Baetge G, Gershon MD (1989) Transient catecholaminergic (TC) cells in the vagus nerves and bowel of fetal mice: relationship to the development of enteric neurons. Dev Biol 132:189-211.

Baetge G, Pintar JE, Gershon MD (1990a) Transiently catecholaminergic (TC) cells in the bowel of fetal rats and mice: precursors of noncatecholaminergic enteric neurons. Dev Biol 141:353-380.

Baetge G, Schneider KA, Gershon MD (1990b) Development and persistence of catecholaminergic neurons in cultured explants of fetal murine vagus nerves and bowel. Development 110:689-701.

Bixby S, Kruger GM, Mosher JT, Joseph NM, Morrison SJ (2002) Cellintrinsic differences between stem cells from different regions of the peripheral nervous system regulate the generation of neural diversity. Neuron 35:643-656.

Blaugrund E, Pham TD, Tennyson VM, Lo L, Sommer L, Anderson DJ, Gershon MD (1996) Distinct subpopulations of enteric neuronal progenitors defined by time of development, sympathoadrenal lineage markers, and Mash-1-dependence. Development 122:309-320.

Branchek TA, Gershon MD (1989) Time course of expression of neuropeptide $\mathrm{Y}$, calcitonin gene related peptide, and NADPH diaphorase activity in neurons of the developing murine bowel and the appearance of 5-hydroxytryptamine in mucosal enterochromaffin cells. J Comp Neurol 285:262-273.

Chen JJ, Zhishan L, Pan H, Murphy DL, Tamir H, Koepsell H, Gershon MD (2001) Maintenance of serotonin in the intestinal mucosa and ganglia of mice that lack the high affinity serotonin transporter (SERT): abnormal intestinal motility and the expression of cation transporters. J Neurosci 21:6348-6361.

Chen JJ, Gershon AA, Li ZS, Lungu O, Gershon MD (2003) Latent and lytic infection of isolated guinea pig enteric ganglia by varicella zoster virus. J Med Virol 70 [Suppl 1]:S71-S78.

Ciliax BJ, Drash GW, Staley JK, Haber S, Mobley CJ, Miller GW, Mufson EJ, Mash DC, Levey AI (1999) Immunocytochemical localization of the dopamine transporter in human brain. J Comp Neurol 409:38-56.

Cochard P, Goldstein M, Black IB (1978) Ontogenetic appearance and disappearance of tyrosine hydroxylase and catecholamines. Proc Natl Acad Sci USA 75:2986-2990.

Cooke HJ (2000) Neurotransmitters in neuronal reflexes regulating intestinal secretion. Ann NY Acad Sci 915:77-80.

Costa M, Furness JB (1971) Storage, uptake and synthesis of catecholamines in the intrinsic adrenergic neurones in the proximal colon of the guinea pig. Z Zellforsch Mikrosk Anat 120:364-385.

Costa M, Furness JB (1984) Somatostatin is present in a subpopulation of noradrenergic nerve fibres supplying the intestine. Neuroscience 13:911-919.

Costa M, Furness JB, McLean JR (1976) The presence of aromatic L-amino acid decarboxylase in certain intestinal nerve cells. Histochemistry 48:129-143.

Eaker EY, Bixler GB, Dunn AJ, Moreshead WV, Mathias JR (1988) Dopamine and norepinephrine in the gastrointestinal tract of mice and the effects of neurotoxins. J Pharmacol Exp Ther 244:438-442.

Furness JB (2000) Types of neurons in the enteric nervous system. J Auton Nerv Syst 81:87-96. 
Furness JB, Costa M (1978) Distribution of intrinsic nerve cell bodies and axons which take up aromatic amines and their precursors in the small intestine of the guinea-pig. Cell Tissue Res 188:527-543.

Furness JB, Costa M, Howe PR (1980) Intrinsic amine-handling neurons in the intestine. Adv Biochem Psychopharmacol 25:367-372.

Galligan JJ, LePard KJ, Schneider DA, Zhou X (2000) Multiple mechanisms of fast excitatory synaptic transmission in the enteric nervous system. J Auton Nerv Syst 81:97-103.

Gershon MD (1999) The enteric nervous system: a second brain. Hosp Pract (Off Ed) 34:31-32, 35-38, 41-32 passim.

Gershon MD (2000) 5-HT (serotonin) physiology and related drugs. Curr Opin Gastroenterol 16:113-120.

Gershon MD, Payette R, Teitelman G, Rothman TP (1984a) Neuronal commitment and phenotypic expression by developing enteric neurons. In: Coexistence of neuroactive substances (Chan-Palay V, Palay S, eds), pp 181-204. New York: Wiley.

Gershon MD, Rothman TP, Joh TH, Teitelman GN (1984b) Transient and differential expression of aspects of the catecholaminergic phenotype during development of the fetal bowel of rats and mice. J Neurosci 4:2269-2280.

Gershon MD, Kirchgessner AL, Wade PR (1994) Functional anatomy of the enteric nervous system. In: Physiology of the gastrointestinal tract, Ed 3 (Johnson LR, Alpers DH, Jacobson ED, Walsh JH, eds), pp 381-422. New York: Raven.

Guillemot F, Lo L-C, Johnson JE, Auerbach A, Anderson DJ, Joyner AL (1993) Mammalian achaete-scute homolog 1 is required for the early development of olfactory and autonomic neurons. Cell 75:463-476.

Hirst GD, Silinsky EM (1975) Some effects of 5-hydroxytryptamine, dopamine and noradrenaline on neurones in the submucous plexus of guineapig small intestine. J Physiol (Lond) 251:817-832.

Holzschuh J, Ryu S, Aberger F, Driever W (2001) Dopamine transporter expression distinguishes dopaminergic neurons from other catecholaminergic neurons in the developing zebrafish embryo. Mech Dev 101:237-243.

Iuvone PM, Galli CL, Garrison-Gund CK, Neff NH (1978) Light stimulates tyrosine hydroxylase activity and dopamine synthesis in retinal amacrine neurons. Science 202:901-902.

Iversen L (2000) Neurotransmitter transporters: fruitful targets for CNS drug discovery. Mol Psychiatry 5:357-362.

Iversen LL (1979) Criteria for establishing a neurotransmitter. In: Neuroscience research program bulletin, non-adrenergic, non-cholinergic neurotransmission mechanisms (Burnstock G, Gershon MD, Hokfelt T, Iversen LL, Kosterlitz HW, Szurszewski JH, eds), p 406. Cambridge, MA: MIT.

Jonakait GM, Wolf J, Cochard P, Goldstein M, Black IB (1979) Selective loss of noradrenergic phenotypic characters in neuroblasts of the rat embryo. Proc Natl Acad Sci USA 76:4683-4686.

Keast JR, Furness JB, Costa M (1984) Origins of peptide and norepinephrine nerves in the mucosa of the guinea pig small intestine. Gastroenterology 86:637-644.

Kirchgessner AL (2001) Glutamate in the enteric nervous system. Curr Opin Pharmacol 1:591-596.

Krantis A (2000) GABA in the mammalian enteric nervous system. News Physiol Sci 15:284-290.

Kruger GM, Mosher JT, Bixby S, Joseph N, Iwashita T, Morrison SJ (2002) Neural crest stem cells persist in the adult gut but undergo changes in self-renewal, neuronal subtype potential, and factor responsiveness. Neuron 35:657-669.

Kusunoki M, Taniyama K, Tanaka C (1985) Dopamine regulation of $[3 \mathrm{H}]$ acetylcholine release from guinea-pig stomach. J Pharmacol Exp Ther 234:713-719.

Lee SY, Im SY, Kim KM (1999) Preparation of dopamine transporterspecific antibodies using molecular cloned genes. Arch Pharm Res 22:262-266

Leibl MA, Ota T, Woodward MN, Kenny SE, Lloyd DA, Vaillant CR, Edgar DH (1999) Expression of endothelin 3 by mesenchymal cells of embryonic mouse caecum. Gut 44:246-252.

Li ZS, Furness JB (1998) Immunohistochemical localisation of cholinergic markers in putative intrinsic primary afferent neurons of the guinea pig small intestine. Cell Tissue Res 294:35-43.

Li ZS, Fox-Threlkeld JE, Furness JB (1998) Innervation of intestinal arteries by axons with immunoreactivity for the vesicular acetylcholine transporter (VAChT). J Anat 192:107-117.
Liu K, Hsiung S, Adlersberg M, Sacktor T, Gershon M, Tamir H (2000) $\mathrm{Ca}^{2+}$-evoked serotonin secretion by parafollicular cells: roles in signal transduction of phosphatidylinositol 3'-kinase, and the $\mathrm{g}$ and $\mathrm{z}$ isoforms of protein kinase C. J Neurosci 20:1365-1373.

Liu M-T, Rothstein JD, Gershon MD, Kirchgessner AL (1997) Glutamatergic enteric neurons. J Neurosci 17:4764-4784.

Lo L, Guillemot F, Joyner AL, Anderson DJ (1994) MASH-1: a marker and a mutation for mammalian neural crest development. Perspect Dev Neurobiol 2:191-201.

Lorang D, Amara SG, Simerly RB (1994) Cell-type-specific expression of catecholamine transporters in the rat brain. J Neurosci 14:4903-4914.

Mann R, Voltattorni CB, Bell C (1989) Extrinsic denervation elevates neuronal aromatic L-amino acid decarboxylase immunoreactivity in rat small intestine. Histochemistry 92:219-223.

Marusich MF, Furneaux HM, Henion PD, Weston JA (1994) Hu neuronal proteins are expressed in proliferating neurogenic cells. J Neurobiol 25:143-155.

Mitsuma T, Rhue H, Hirooka Y, Kayama M, Wago T, Takagi J, Adachi K, Ping J, Ohtake M, Nogimori T, Sakai J (1998) Distribution of dopamine transporter in the rat: an immunohistochemical study. Endocr Regul 32:71-75.

Molinoff PB, Axelrod J (1971) Biochemistry of catecholamines. Annu Rev Biochem 40:465-500.

Neunlist M, Reiche D, Michel K, Pfannkuche H, Hoppe S, Schemann M (1999) The enteric nervous system: region and target specific projections and neurochemical codes. Eur J Morphol 37:233-240.

Pan H, Gershon MD (2000) Activation of intrinsic afferent pathways in submucosal ganglia of the guinea pig small intestine. J Neurosci 20:3295-3309.

Pham TD, Gershon MD, Rothman TP (1991) Time of origin of neurons in the murine enteric nervous system. J Comp Neurol 314:789-798.

Portbury AL, Chandra R, Groelle M, McMillian MK, Elias A, Herlong JR, Rios M, Roffler-Tarlov S, Chikaraishi DM (2003) Catecholamines act via a beta-adrenergic receptor to maintain fetal heart rate and survival. Am J Physiol Heart Circ Physiol 284:H2069-H2077.

Scheibner J, Trendelenburg AU, Hein L, Starke K, Blandizzi C (2002) Alpha 2-adrenoceptors in the enteric nervous system: a study in alpha 2Aadrenoceptor-deficient mice. Br J Pharmacol 135:697-704.

Shichijo K, Sakurai-Yamashita Y, Sekine I, Taniyama K (1997) Neuronal release of endogenous dopamine from corpus of guinea pig stomach. Am J Physiol 273:G1044-G1050.

Singaram C, Ashraf W, Gaumnitz EA, Torbey C, Sengupta A, Pfeiffer R, Quigley EM (1995) Dopaminergic defect of enteric nervous system in Parkinson's disease patients with chronic constipation. Lancet 346:861-864.

Steele PA, Brookes SJH, Costa M (1991) Immunohistochemical identification of cholinergic neurons in the myenteric plexus of guinea pig small intestine. Neuroscience 45:227-239.

Tamir H, Liu KP, Heath M, Adlersberg M, Gershon MD (1994) Stimulusinduced secretion and vesicle acidification in serotonergic paraneurons (parafollicular cells): the role of voltage-gated $\mathrm{Ca}^{2+}$ channels. Soc Neurosci Abstr 20:1719.

Teitelman G, Joh TH, Reis DJ (1978) Transient expression of a noradrenergic phenotype in cells of the rat embryoinic gut. Brain Res 158:229-234.

Teitelman G, Gershon MD, Rothman TP, Joh TH, Reis DJ (1981) Proliferation and distribution of cells that transiently express a catecholaminergic phenotype during development in mice and rats. Dev Biol 86:348-355.

Thomas SA, Matsumoto AM, Palmiter RD (1995) Noradrenaline is essential for mouse fetal development. Nature 374:643-646.

Walker JK, Gainetdinov RR, Mangel AW, Caron MG, Shetzline MA (2000) Mice lacking the dopamine transporter display altered regulation of distal colonic motility. Am J Physiol Gastrointest Liver Physiol 279:G311-G318.

Weiner N (1970) Regulation of norepinephrine biosynthesis. Annu Rev Pharmacol 10:273-290.

Wood JD (1999) Neurotransmission at the interface of sympathetic and enteric divisions of the autonomic nervous system. Chin J Physiol 42:201-210.

Young HM, Ciampoli D, Hsuan J, Canty AJ (1999) Expression of Ret-, p75(NTR)-, Phox2a-, Phox2b-, and tyrosine hydroxylase-immunoreactivity by undifferentiated neural crest-derived cells and different classes of enteric neurons in the embryonic mouse gut. Dev Dyn 216:137-152.

Zhou QY, Palmiter RD (1995) Dopamine-deficient mice are severely hypoactive, adipsic, and aphagic. Cell 83:1197-1209.

Zhou QY, Quaife CJ, Palmiter RD (1995) Targeted disruption of the tyrosine hydroxylase gene reveals that catecholamines are required for mouse fetal development. Nature 374:640-643. 